\title{
PENTINGNYA MENJAGA KESEHATAN \\ DI MUSIM PANDEMI COVID-19
}

\author{
Elma Lufita Umara \\ Institut Ilmu Kesehatan Surya Mitra Husada \\ elmaluvitaumaraumara@gmail.com
}

\begin{abstract}
Abstrak
Dalam artikel ini penulis membahas tentang pentingnya menjaga kesehatan dan pola hidup sehat di musim pandemi covid-19. Munculnya pandemi ini menjadi permasalahan yang di hadapi sekarang. Pencegahannya dengan cara melakukan menjaga kesehatan dan menjaga pola hidup sehat. Pemerintah mengeluarkan aturan dengan menerapkan $3 \mathrm{M}$ yaitu, memakai masker, mencuci tangan, dan menjaga jarak. Selain itu kita juga dianjurkan untuk meningkatkan imun tubuh supaya dapat menangkal virus covid-19. Salah satu cara untuk meningkatkan imun tubuh adalah menerapkan pola hidup sehat. Pola hidup sehat merupakan hal yang wajib kita lakukan, terutama pada masa pandemi. Dengan memilah dan mengatur pola hidup yang sehat, tentunya tubuh kita akan merasakan banyak manfaat.
\end{abstract}

\section{Latar Belakang}

Permasalahan yang di hadapi sekarang adalah penyebaran virus covid-19 di seluruh dunia. Dengan penyebaran yang sangat cepat Indonesia adalah salah satu negara yang terkena dampak dari penyebaran virus tersebut. Lebih dari 200 negara yang sudah terkena virus covid-19 dengan penyebaran yang begitu cepat maka Indonesia melakukan penanganan dan pencegahan agar penyebaran virus covid19 tidak sampai meluas ke seluruh rakyat Indonesia. Pencegahannya dengan cara melakukan menjaga kesehatan dan menjaga pola hidup sehat. Pemerintah mengeluarkan aturan dengan menerapkan $3 \mathrm{M}$ yaitu, memakai masker, mencuci tangan, dan menjaga jarak. Selain itu kita juga dianjurkan untuk meningkatkan imun tubuh supaya dapat menangkal virus covid-19. Salah satu cara untuk meningkatkan imun tubuh adalah menerapkan pola hidup sehat. Pola hidup sehat merupakan hal yang wajib kita lakukan, terutama pada masa pandemi. 
Dengan memilah dan mengatur pola hidup yang sehat, tentunya tubuh kita akan merasakan banyak manfaat.

Kita hanya perlu memperhatikan kebiasaan kecil sehari-hari dan mengubahnya supaya lebih bermanfaat untuk kesehatan tubuh. Menurut peraturan Kementerian Kesehatan Republik Indonesia Nomor 28 Tahun 2019 Tentang Angka Kecukupan Gizi yang Dianjurkan untuk Masyarakat Indonesia yaitu, untuk laki-laki disarankan mengkonsumsi serat sebanyak 28-37 gram per hari. Sedangkan perempuan, perlu konsumsi serat sebanyak 27-32 gram per hari. Pola hidup sehat tidak hanya tentang fisik tetapi juga dengan kebutuhan mental kita. Memiliki banyak tekanan akan membuat pikiran kita menjadi stress, oleh sebab itu sangat dianjurkan untuk berpikir positif. Berpikir positif dapat membuat hati kita menjadi tentram dan dapat mengalahkan berbagai penyakit termasuk saat kita sedang mengalami tekanan. Dengan mengubah cara berpikir menjadi positif, maka kesehatan mental kita akan menjadi lebih baik. Dengan pola hidup sehat akan menciptakan harapan hidup lebih lama. Manfaat lain yang kita dapatkan yaitu meningkatkan imun tubuh. Imun tubuh dapat mencegah penyakit masuk ke dalam tubuh kita, termasuk virus Covid19.

\section{Kasus/ Masalah}

Hingga saat ini Indonesia masih berjuang untuk melawan virus Covid-19. Setiap harinya kasus angka positif Covid-19 selalu bertambah. Masyarakat diingatkan oleh pemerintah agar mengikuti dan mematuhi protokol kesehatan, baik dari menggunakan masker, mencuci tangan dan menjaga jarak karena hal tersebut menjadi kebutuhan kita semua sejak adanya pandemi.Tentu tidak mudah menghentikan penyebaran virus Covid-19. Untuk itu kita dianjurkan meningkatkan imun tubuh supaya dapat menangkal virus Covid-19. Salah satu cara meningkatkan imun tubuh adalah menerapkan pola hidup sehat. Pola hidup sehat merupakan hal yang wajib kita lakukan, terutama pada masa pandemi. Dengan memilah dan mengatur pola hidup sehat, tentunya tubuh kita akan merasakan banyak manfaat. Kita hanya perlu memperhatikan kebiasaan kecil sehari-hari dan mengubahnya supaya lebih bermanfaat untuk kesehatan tubuh. 
Semua orang pasti ingin selalu sehat dan terhindar dari berbagai penyakit. Sebab, dengan tubuh dan pikiran yang selalu sehat, kesejahteraan hidup dapat meningkat. Menjaga kesehatan pun nyatanya tidak sesulit yang dibayangkan, salah satunya adalah dengan menerapkan gaya hidup sehat setiap hari. Gaya hidup sehat adalah sebuah komitmen jangka panjang untuk menjaga atau melakukan beberapa hal agar mampu mendukung fungsi tubuh, sehingga berdampak baik bagi kesehatan. Beberapa upaya yang bisa dilakukan untuk menerapkan pola hidup sehat adalah menjaga asupan makanan sehat dengan diet dan nutrisi, berolahraga, melakukan kegiatan positif untuk menghindari stres, dan masih banyak lagi. Dengan melakukan hal ini, maka kualitas hidup pun bisa meningkat dan membawa pengaruh positif bagi lingkungan

\section{Tinjauan Pustaka}

Kepatuhan berasal dari kata patuh. Menurut KBBI (Kamus Besar Bahasa Indonesia), patuh berarti suka menurut perintah, taat kepada perintah, aturan, dan berdisiplin (Waskito, 2012). Kepatuhan merupakan sikap atau ketaatan untuk memenuhi anjuran petugas kesehatan tanpa dipaksa untuk melakukan tindakan

(Fandinata \& Ernawati, 2020). Menurut Purwati \& Amin (2016), kepatuhan adalah memenuhi permintaan orang lain, didefinisikan sebagai suatu tindakan atau perbuatan yang dilakukan berdasarkan keinginan orang lain atau melakukan apa apa yang diminta oleh orang lain.

Bagian-Bagian 5M:

\section{Menggunakan masker}

Masker adalah salah satu Alat Pelindung Diri (APD) yang digunakan untuk melindungi mulut, hidung, dan wajah dari pathogen yang ditularkan melalui udara (airborne), droplet, maupun percikan cairan tubuh yang terinfeksi (Basri, 2016). Penggunaan masker medis adalah salah satu langkah pencegahan yang dapat membatasi penyebaran penyakit saluran pernapasan tertentu yang diakibatkan oleh virus, termasuk Covid-19 (WHO, 2020). Penggunaan masker memang terbukti efektif mampu menekan penyebaran Covid-19 bila diimbangi juga dengan melaksanakan protokol kesehatan lainnya seperti, rajin mencuci tangan dengan 
sabun dan air mengalir serta jaga jarak dengan orang lain (Yulianto, 2020). Menurut Yulianto (2020), penggunaan masker wajib digunakan oleh tenaga kesehatan, orang yang sedang sakit, orang yang merawat orang sakit, serta orang sehat yang hendak bepergian untuk kepentingan penting dan mendesak. Berikut panduan

\section{Cara menggunakan masker yang tepat, yaitu :}

a. Sebelum memasang masker, cuci tangan terlebih dulu dan menggunakan sabun dan air mengalir selama minimal 20 detik. Bila tidak tersedia air mengalir, gunakan cairan pembersih tangan (dengan kandungan alkohol minimal 60\%).

b. Pasang masker hingga menutupi hidung, mulut, sampai dagu. Pastikan tidak ada sela antara wajah dan masker.

c. Jangan membuka dan menutup masker berulang-ulang saat sedang digunakan. Jangan menyentuh masker, bila tersentuh, cuci tangan dengan memakai sabun danair mengalir selama 20 detik atau bila tidak ada, gunakan cairan pembersih tangan

(dengan kandungan alkohol minimal 60\%).

d. Ganti masker yang sudah basah atau lembab dengan masker baru. Masker medis hanya boleh digunakan sekali. Masker kain dapat digunakan berulang kali setelah dicuci dengan air bersih dan detergen.

e. Cara membuka masker adalah dengan melepaskan dari belakang. Jangan menyentuh bagian depan masker. Buang segera masker sekali pakai di tempat sampah tertutup atau kantong plastik. Untuk masker kain, segera cuci dengan detergen lalu dikeringkan. Pemerintah Republik Indonesia melalui Menteri Kesehatan juga telah mengeluarkan panduan menggunakan masker dengan benar. Berikut ini poin-poinnya sebagaimana dikutip dari Surat Edaran Protokol Isolasi Diri Sendiri dalam Penanganan Covid-19 yang ditandatangani Menkes Terawan Agus Putranto tanggal 16 Maret 2020.

Berikut ini perinciannya :

1) Masker digunakan oleh :

a) Orang dengan gejala pernapasan, misal batuk, bersin atau kesulitan bernapas. Termasuk ketika mencari pertolongan medis. 
b) Orang yang memberikan perawatan kepada individu dengan gejala pernapasan.

c) Petugas kesehatan, ketika memasuki ruangan dengan pasien atau merawat seseorang dengan gejala pernapasan.

2) Masker medis tidak diperuntukkan untuk anggota masyarakat umum yang tidak memiliki gejala penyakit pernapasan. Jika masker digunakan, langkah yang baik harus diikuti tentang memakai, melepas, dan membuangnya serta tindakan kebersihan tangan setelah menggunakannya.

3) Cara penggunaan masker sekali pakai :

a) Pastikan masker menutupi mulut, hidung, dagu dan bagian yang berwarna berada di bagian depan.

b) Tekan bagian atas masker supaya mengikuti bentuk hidung dan tarik ke belakang di bagian bawah dagu.

c) Lepaskan masker yang telah digunakan dengan hanya memegang tali dan langsung buang ke tempat sampah tertutup. Cuci tangan menggunakan sabun dan air mengalir atau hand sanitizer setelah membuang masker yang telah digunakan.

d) Hindari menyentuh masker saat menggunakannya.

e) Jangan gunakan kembali masker sekali pakai. Ganti secara rutin apabila kotor atau basah.

\section{Mencuci tangan}

Virus corona menular melalui droplet, yaitu cairan atau cipratan liur yang dikeluarkan seseorang dari hidung atau mulut saat bersin, batuk, bahkan berbicara. Droplet ukurannya yang kecil dan ringan dapat menyebar diperkirakan sejauh 1 hingga 2 meter, kemudian jatuh sesuai dengan hukum gravitasi. Droplet yang berisi virus ini jatuh diatas permukaan benda mati, maka benda tersebut akan terkontaminasi dan berpotensi menyebarkan infeksi. Tangan apabila tanpa sengaja menyentuh fomite, virus akan menempel, kemudian ketika tangan yang sudah terkontaminasi menyentuh wajah, virus akan lebih mudah masuk ke tubuh kita melalui mukosa mulut, hidung, ataupun mata (Ais, 2020). mencuci tangan secara rutin dan menyeluruh dengan durasi minimal 20 detik 
menggunakan sabun dan air bersih mengalir. Setelah itu, keringkan tanganmenggunakan kain yang bersih atau tisu (Anies, 2020).

\section{Menjaga jarak}

Menjaga jarak setidaknya 1 meter dari orang lain. Jarak yang terlalu dekat memungkinkan dapat menghirup tetesan air dan hidung atau mulut orang yang mungkin terinfeksi Covid-19 ketika seseorang itu bersin atau batuk (Santika, 2020). Cara ini memang bukanlah satusatunya dan yang paling efektif, namun perlu dilakukan untuk menghambat pertumbuhan virus corona yang sangat pesat sampai ditemukannya vaksin (Delfirman, dkk, 2020).

\section{Menjauhi kerumunan}

Kita semua diminta untuk menjauhi kerumunan saat berada di luar rumah. Semakin banyak dan sering kita bertemu dengan orang lain, kemungkinan terinfeksi virus corona bisa semakin tinggi (Anastasia, 2021). Hindari berkumpul dengan teman dan keluarga, termasuk berkunjung/bersilaturahmi tatap muka dan menunda kegiatan bersama (Kandari \& Ohorella, 2020).

\section{Mengurangi mobilitas}

Bila tidak ada kepentingan yang mendesak, tetaplah untuk berada di dalam rumah. Meski tubuh kita dalam keadaan sehat dan tidak ada gejala penyakit, belum tentu saat pulang ke rumah dengan keadaan yang masih sama (Anastasia, 2021). Menurut Kemenkes RI tahun 2020, dalam jurnal (Kandari \& Ohorella, 2020) menyatakan untuk sementara waktu sebaiknya tetap di rumah dan melaksanakan ibadah di rumah.

\section{Pembahasan}

Pengertian covid-19:

Coronavirus adalah kumpulan virus yang bisa menginfeksi sistem pernapasan. Pada banyak kasus, virus ini hanya menyebabkan infeksi pernapasan ringan, seperti flu. Namun, virus ini juga bisa menyebabkan infeksi pernapasan berat, seperti infeksi paru-paru (pneumonia).Virus ini menular melalui percikan dahak (droplet) dari saluran pernapasan, misalnya ketika berada di ruang tertutup yang 
ramai dengan sirkulasi udara yang kurang baik atau kontak langsung dengan droplet.

Selain virus SARS-CoV-2 atau virus Corona, virus yang juga termasuk dalam kelompok ini adalah virus penyebab Severe Acute Respiratory Syndrome (SARS) dan virus penyebab Middle-East Respiratory Syndrome (MERS). Meski disebabkan oleh virus dari kelompok yang sama, yaitu coronavirus, COVID-19 memiliki beberapa perbedaan dengan SARS dan MERS, antara lain dalam hal kecepatan penyebaran dan keparahan gejala.

\section{Dampak covid- 19}

Coronavirus adalah kumpulan virus yang bisa menginfeksi sistem pernapasan. Pada banyak kasus, virus ini hanya menyebabkan infeksi pernapasan ringan, seperti flu. Namun, virus ini juga bisa menyebabkan infeksi pernapasan berat, seperti infeksi paru-paru (pneumonia).Virus ini menular melalui percikan dahak (droplet) dari saluran pernapasan, misalnya ketika berada di ruang tertutup yang ramai dengan sirkulasi udara yang kurang baik atau kontak langsung dengan droplet.

Selain virus SARS-CoV-2 atau virus Corona, virus yang juga termasuk dalam kelompok ini adalah virus penyebab Severe Acute Respiratory Syndrome (SARS) dan virus penyebab Middle-East Respiratory Syndrome (MERS). Meski disebabkan oleh virus dari kelompok yang sama, yaitu coronavirus, COVID-19 memiliki beberapa perbedaan dengan SARS dan MERS, antara lain dalam hal kecepatan penyebaran dan keparahan gejala.

\section{Kesimpulan}

Hingga saat ini Indonesia masih berjuang untuk melawan virus

Covid-19. Setiap harinya kasus angka positif Covid-19 selalu bertambah. Masyarakat diingatkan oleh pemerintah agar mengikuti dan mematuhi protokol kesehatan, baik dari menggunakan masker, mencuci tangan dan menjaga jarak karena hal tersebut menjadi kebutuhan kita semua sejak adanya pandemi. Tentu tidak mudah menghentikan penyebaran virus Covid-19. Untuk itu kita dianjurkan meningkatkan imun tubuh supaya dapat menangkal virus Covid-19. 
Salah satu cara meningkatkan imun tubuh adalah menerapkan pola hidup sehat.Pola hidup sehat merupakan hal yang wajib kita lakukan, terutama pada masa pandemi. Dengan memilah dan mengatur pola hidup sehat, tentunya tubuh kita akan merasakan banyak manfaat. Kita hanya perlu memperhatikan kebiasaan kecil sehari-hari dan mengubahnya supaya lebih bermanfaat untuk kesehatan tubuh.

\section{Daftar Pustaka}

https://dinkes.bantulkab.go.id/berita/1177-pentingnya-menjagapola-hidup-sehat-selama-masa-pandemi

http://ners.unair.ac.id/site/index.php/news-fkp-unair/30-lihat/1181dampak-covid-19-dalam-bidang-kesehatan

https://wawasanproklamator.com/artikel/418/pentingnya-menjagakesehatan-dengan-pola-hidup-sehat.html 